\author{
Anna Engelking \\ engelking@ispan.waw.pl
}

\title{
Wokół pierwszej polskiej systematyki zamówień. O zapomnianej propozycji Józefa Obrębskiego
}

\begin{abstract}
Engelking Anna, Wokót pierwszej polskiej systematyki zamówień. O zapomnianej propozycji Józefa Obrębskiego (The First Polish Systematics of Spells against Illness. On the Forgotten Proposal of Józef Obrębski). „Poznańskie Studia Slawistyczne” 3. Poznań 2012. Adam Mickiewicz University Press, pp. 61-74. ISBN 978-83-232-2473-0. ISSN 2084-3011.

The author discusses the first Polish systematics of magic spells against illness, which was proposed by Józef Obrębski in a brochure Index for „Treating the Polish people” by Henryk Biegeleisen in 1931. Obrębski introduced a division of spells into 9 groups, separated on the basis of their content, form and function. It was not an autonomous development. It have been created for the needs of someone else's work and on the margin of a broader classification of material in the field of folk medicine as a whole. However, the proposal of Obrębski can be regarded as a serious outline covering all material concerning the systematics of spells against illness. In the following parts of the article the author sets the discussed work in a due context, locating it in the history of Polish research on the genre of spells. She recalls the first nineteenth-century works and analyses a possible impact of the Obrębski's systematics on the subsequent approaches to the subject.
\end{abstract}

Keywords: spells, folk medicine, systematics, literary genetics, the history of folklore, the history of ethnology

Pamięci Heleny Kapełuś

Propozycja pierwszej polskiej systematyki zamówieńn ${ }^{1}$ wyrosła, jak się wydaje, z irytacji źle napisaną książką Henryka Biegeleisena Lecznictwo ludu polskiego. Została ona wydana w 1929 roku w Krakowie, a jej kry-

\footnotetext{
${ }^{1}$ Nazwę zamówienie odnoszę do tekstu słownego, zamawianie - do rytualnego aktu mówienia-działania, zgodnie z tradycją genologii folklorystycznej, w której zamawianie „utożsamiane jest z aktem działania”, zamówienie - „z jego wytworem”. Cf. S. Niebrze-
} 
tycznym czytelnikiem był asystent profesora Kazimierza Moszyńskiego w Studium Słowiańskim Uniwersytetu Jagiellońskiego - Józef Obrębski.

W periodykach etnograficznych tego okresu znajdujemy dwie recenzje książki Biegeleisena. Pierwsza z nich to omówienie autorstwa Adama Fischera, zamieszczone w „Ludzie”, druga - opublikowana w „Ludzie Słowiańskim" recenzja pióra Obrębskiego. W zestawieniu z bezkrytycznie referującym autorski punkt widzenia tekstem Fischera, który wprawdzie wytyka Biegeleisenowi „dziwny dobór ilustracyj” i ,liczne błędy drukarskie", lecz poza tym ocenia jego dzieło jednoznacznie pozytywnie jako posiadające „,bardzo bogatą treść, ciekawą pod względem historyczno-kulturalnym i mogącą wzbudzić zainteresowanie nawet szerszych kół czytelników"2. W recenzji Obrębskiego widać pasję krytyczną początkującego badacza, który wymaga od siebie i od środowiska przestrzegania standardów myślenia naukowego. Recenzja Fischera mogła być oparta na bardzo pobieżnej lekturze: lwowski profesor krótko przedstawia treść książki i konwencjonalnie chwali autora. Recenzja Obrębskiego - „dość ostra, choć na ogół słuszna”, jak ocenił ją Moszyński ${ }^{3}$ - jest efektem bardzo wnikliwej lektury; zawiera zestaw uzasadnionych zarzutów natury merytorycznej i warsztatowej.

Wartość Lecznictwa ludu polskiego młody recenzent dostrzegł w tym, że autor „wykorzystuje szereg źródeł, rozrzuconych po najrozmaitszych dziełach i wydawnictwach i opublikowuje materiał, dotychczas - ze względu na utrudniony do niego dostęp - nieznany lub nieuwzględniany" ". Słabości pracy Biegeleisena wymienia liczne. Po pierwsze, wskazuje na spostrzeżenia teoretyczne autora dotyczące genezy czy funkcji omawianych zjawisk, w których

gowska-Bartmińska, Wzorce tekstów ustnych w perspektywie etnolingwistycznej, Lublin 2007, s. 109. Robię jednakże jeden istotny wyjątek: referując ujęcie Obrębskiego, który nie czynił takiego rozróżnienia, pozostawiam używaną przez niego w odniesieniu do tekstów nazwę zamawianie. Podobnie przy omawianiu propozycji innych badaczy - posługuję się stosowaną przez nich terminologią.

2 A. Fischer, [recenzja z:] Henryk Biegeleisen, „Lecznictwo ludu polskiego”, „Lud” t. XXIX, 1930, s. 165.

${ }^{3}$ K. Moszyński, Nieco uwag krytycznych, „Lud Słowiański” t. II, z. 2, 1931, s. B264.

${ }^{4}$ J. Obrębski, [recenzja z:] H. Biegeleisen, Lecznictwo ludu polskiego (z 100 rycinami), Kraków 1929, „Lud Słowiański” t. II, 1931, s. B255. 
niezręczność sformułowania (...) idzie w parze z nieusprawiedliwioną fantastycznością pomysłów [jak np. wywód, w którym] genezy praktyki leczniczej, polegającej na tym, iż tkniętych atakiem epilepsji ocuca się, dotykając ich „rogami łosia wziętymi w czasie rykowiska" (...) każe nam autor dopatrywać się w ludożerstwie, którego przeżytkiem ma być powyższy zabieg!5.

Po drugie, Obrębski zarzuca Biegeleisenowi - i to jest jego zasadniczy zarzut - brak konsekwencji w klasyfikacji omawianego materiału.

Autor mianowicie nie może się zdecydować ani na układ według chorób czy ich odmian, ani też na układ według sposobów i środków leczenia. Naturalnym skutkiem tego wahania jest nieustanne przerzucanie się od jednego układu do drugiego. W rezultacie powstaje duża chaotyczność treści ${ }^{6}$.

Dalej, prowadzeni przez uzasadniające wywód przykłady, czytamy o sprzecznościach definicji, nieścisłości terminów, błędach w przytaczanych nazwach i w tytułach publikacji (od których ,roi się wprost”), wreszcie o niewiążących się z treścią książki ilustracjach, które nadają jej „specjalny posmak sensacyjności, co (...) zasługuje chyba na potępienie", .

Wydawcą książki Biegeleisena była Komisja Etnograficzna PAU. Komisja, wychodząc z założenia, że ,korzystanie z istotnie ogromnego materiału, zestawionego w pracy p. Biegeleisena jest znacznie utrudnione przez brak indeksu", , zleciła wykonanie takowego Józefowi Obrębskiemu. Nad Indeksem do Lecznictwa ludu polskiego Henryka Biegeleisena pracował

${ }^{5}$ Ibidem, s. B255-B256.

${ }^{6}$ Ibidem, s. B257.

${ }^{7}$ Ibidem, s. B259. Opinia Obrębskiego jest podzielana przez współczesnych folklorystów, których zdaniem dorobek H. Biegeleisena „budzi tyleż szacunku, co i zastrzeżeń. Bogactwo materiałowe książek Biegeleisena nie służy pogłębianiu analizy, która, choć niejednokrotnie trafna, przynosi w sumie ubóstwo wniosków. Inteligencja uczonego zagrzebana została pod stosami dokumentacji, ta zaś - odnotowana w imponujących rejestrach bibliograficznych, lecz nie lokalizowana szczegółowo - jest dla czytelnika naukowo nieprzydatna. (...) Dorobek H. Biegeleisena, surowo oceniony przez J. Krzyżanowskiego, budzi uznanie rozległością badań, zniechęca, zwłaszcza w jego ostatnich książkach, szpargałowym monumentalizmem, który sprawia, że wertowanie ich podobne jest szukaniu igły w stogu siana". R. Wojciechowski, Filologowie wobec folkloru, w: Dzieje folklorystyki polskiej 1864-1918, red. H. Kapełuś, J. Krzyżanowski, Warszawa 1982, s. 613-614.

${ }^{8}$ J. Obrębski, Indeks do „Lecznictwa ludu polskiego” Henryka Biegeleisena, Kraków 1931, s. 3. 
on, jak należy przypuszczać, równolegle z pisaniem recenzji. Obie pozycje ukazały się w 1931 roku i stanowią dopełniającą się całość.

Indeks rzeczowy do pracy Biegeleisena autorstwa Obrębskiego jest konstruktywną konsekwencją krytycznej opinii zawartej w recenzji. $\mathrm{W}$ istocie jest on więcej niż tylko indeksem: jego autor zaproponował własną systematykę - poziom organizacji materiału, którego tak mu brakowało $\mathrm{w}$ oryginalnym opracowaniu. Jednocześnie zdecydował się nie uwzględniać tego, co „wobec częstych błędów i omyłek" nie budziło w książce zaufania: materiału słownikowego i terminologicznego. Podszedł więc do zadania w sposób indywidualny i twórczy. Swoje zestawienie indeksowe poprzedził pięcioipółstronicowym wstępem, w którym zaproponował dwa układy systematyczne: sposobów leczenia i tekstów zamówień. Pisał:

Zmuszony byłem zaryzykować w indeksie własną systematykę faktów, składających się na terapię ludową. Oparłem ją przy tym zasadniczo na innych podstawach aniżeli te, jakimi się posłużył autor. Operując mianowicie materiałem, podanym z drugiej ręki, materiałem, który należało poklasyfikować w sposób możliwie kompletny, przejrzysty i jak najmniej podlegający dyskusji, za najdogodniejszą uznałem systematykę, ograniczającą się wyłącznie do stanowiska czysto opisowego. Tym samym zrezygnowałem z jakiegokolwiek grupowania odnośnych faktów zależnie od ich genezy, czy też na podstawie mniej lub bardziej uzasadnionej interpretacji psychologicznej. W pierwszym więc rzędzie wyłączyłem tutaj klasyfikację zarówno sposobów, jak i środków leczenia zależnie od ich przypuszczalnego par excellence medycznego czy też wyłącznie magicznego charakteru. (...) Rezultatem tego było między innymi pominięcie w indeksie szeregu zaczerpniętych z systematyki magii tradycyjnych definicyj czy terminów ${ }^{10}$.

Trzeba podkreślić wagę, jaką Obrębski przywiązywał do systematyki. W tej kwestii był bez watpienia uczniem swego mistrza; w okresie poprzedzającym pracę nad Biegeleisenem towarzyszył Moszyńskiemu przy przygotowywaniu do druku pierwszego tomu Kultury ludowej Stowian - dzieła systematyzującego tradycyjną kulturę materialną - i musiał zdawać sobie sprawę, jak wysoko jego profesor stawia zadanie systematyzowania wytworów kultury. „Dążyć się powinno do całkowitego wydzielenia systema-

\footnotetext{
${ }^{9}$ Ibidem, s. 9.

${ }^{10}$ Ibidem, s. 4-5.
} 
tyki” - deklarował Moszyński. „Wszystkie zasadnicze typy i główne odmiany wytworów kultury materialnej, duchowej i społecznej powinny być wyodrębnione, określone i podzielone na grupy"11. Materiał Biegeleisena został w Indeksie opracowany zgodnie z tym postulatem.

Jak zatem przedstawia się zaproponowana przez Obrębskiego systematyka?

Zacznijmy od ludowych sposobów leczenia. Autor podzielił je na trzy grupy, mianowicie: sposoby leczenia za pomoca praktyk dokonywanych bezpośrednio na pacjencie (tu umieścił np. bicie, gryzienie, kłucie chorego miejsca, przewlekanie chorego przez rozłupane drzewo czy straszenie chorego lub choroby, jak również leczenie za pomocą środków leczniczych używanych wewnętrznie bądź zewnętrznie), za pomocą praktyk dokonywanych nad przedmiotami, które pozostają lub pozostawały w związku $\mathrm{z}$ chorym (jak porzucanie, palenie, topienie, zakopywanie takich przedmiotów) oraz sposoby leczenia za pomocą praktyk, które nie są dokonywane ani bezpośrednio na pacjencie, ani nad przedmiotami pozostającymi z nim w związku (np. dręczenie roślin czy niszczenie lub porzucanie nitki z wę-

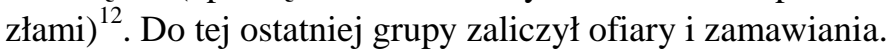

Ze względu na to, że zamówienia stanowią w książce Biegeleisena „najobszerniejszą podgrupę, Obrębski zdecydował się umieścić je „poza systematyką sposobów leczenia”. Zaproponował więc osobne ich ujęcie „pobieżną klasyfikację różnych typów wątków, uwzględniającą ujawnione przez autora książki usiłowania i zamierzenia, idące w tym kierunku"; w jej wyniku wyodrębnił „tylko typy bardziej wyraziste i przejrzyste" ${ }^{\text {"13. }}$. Systematyka ta, wydzielająca obecne w zamówieniach „typy wątków”

${ }^{11}$ K. Moszyński, Kultura ludowa Stowian, cz. I: Kultura materialna, Kraków 1929, s. V.

${ }^{12}$ Identyczny (literalnie) podział ,zabiegów leczniczych u ludów słowiańskich” zastosował Moszyński w swoim systematycznym opisie medycyny ludowej. Cf.: K. Moszyński, Kultura ludowa Stowian, cz. II: Kultura duchowa, z. 1, Kraków 1934, s. 201, 228. Do grupy ostatniej, obok zamawiań, zaliczył modlitwy, przebłagiwania obrażonych żywiołów i ,szereg praktyk o bardzo różnorodnej genezie". Ibidem, s. 228-229. Dziś nie sposób stwierdzić, czy powyższa klasyfikacja sposobów leczenia pochodzi od Moszyńskiego i została zastosowana przez Obrębskiego w Indeksie, czy też jej autorem jest Obrębski, Moszyński zaś wykorzystał ją w swojej późniejszej książce, czy też powstała w efekcie wspólnej pracy nauczyciela i ucznia.

${ }^{13}$ J. Obrębski, Indeks..., s. 7. 
(zgodnie ze współczesnymi kategoriami należałoby tu mówić o motywach i ich wzajemnych relacjach ${ }^{14}$ ), ma postać następująca:

1. Pierwszą grupę („łatwą do wyodrębnienia”) stanowią zamawiania oparte na motywie wypędzania choroby. Należą tu teksty mówiące o wypędzeniu choroby na pustkowia, stopniowym wypędzaniu choroby $\mathrm{z}$ ciała i szczegółowym wypędzaniu choroby z ciała. Ten potrójny podział Obrębski ilustruje przykładami z opracowania Biegeleisena: a) „Idźże, postrzale, na bory, na lasy”, b) „Chorobo, wyjdź z oka, a idź do głowy, z głowy do ręki, z ręki do nogi, z nogi wejdź do ziemi”, c) „Z twoich ócz, uszu, nosa, mózgu, języka wydalam tkwiące ci w głowie suchoty".

2. Do drugiej grupy, której wyodrębnienie nie było dla Obrębskiego tak oczywiste jak pierwszej, zaliczył zamawiania, w których zawarty jest rozkaz zmiany miejsca lub czynności. „Czasem odnosi się wrażenie - komentował - że jeśli chodzi np. o rozkaz zmiany miejsca, to stanowią one kombinację wypędzania choroby na pustkowia $\mathrm{z}$ wypędzaniem jej $\mathrm{z}$ ciała" ${ }^{\prime \prime}$. Dla zilustrowania tego typu zamówień przytoczył tekst:

Tutaj tej chorobie w głowie nie łamać, w uchu nie strzykać, zębów nie łamać, krwi nie ronić, miejsca tu nie szukać, ale iść sobie na szerokie brody, na głębokie wody, tam jej piaski przesypywać, wody mierzyć i kamienie łupać, brody rozszerzać, jakie są głębokie, jakie są szerokie.

Rzeczywiście, odróżnienie grupy pierwszej od drugiej jest nieostre; wydaje się, że systematyk nie był tu do końca konsekwentny. Może ten typ tekstów powinien był ujać jako czwartą podgrupę pierwszej? ${ }^{16}$.

3. Kolejna grupa, podobnie jak pierwsza „wyraźnie wyodrębniająca się", to zamawiania normujące wadliwy układ ciała lub kości. Ich odrębność od innych łatwo uchwycić, ponieważ obok kryterium treści wyróżnia

14 „Teoretycy literatury i leksykografowie definiują motyw podobnie: jako elementarną, tzn. dającą się analitycznie wyodrębnić, jednostkę konstrukcyjną świata przedstawionego w utworze, jego składnik «pierwiastkowy»: zdarzenie, przedmiot, sytuację, przeżycie itp.". S. Niebrzegowska-Bartmińska, op. cit., s. 49. Szczegółowo o stanie badań nad motywem jako podstawowym składnikiem tekstu, vide ibidem, s. 49-75.

${ }^{15}$ J. Obrębski, Indeks..., s. 7.

${ }^{16}$ O segmentach zamówień, mówiących skąd i dokąd odsyłana jest choroba, cf. S. Niebrzegowska-Bartmińska, op. cit., s. 166-169. S. Niebrzegowska-Bartmińska uznaje formuły odsyłania choroby wraz ze wskazaniem miejsca, skąd i dokąd ma być odesłana, za obligatoryjny składnik części dialogowej/monologowej zamówienia. Ibidem, s. 155-156. 
je kryterium funkcjonalne: ,z reguły stosowane są one do tego rodzaju schorzeń, jak złamanie kości, zwichnięcie itp."17. Brzmią na przykład: „Niech będzie skóreczka ze skóreczką, kosteczka z kosteczką, krewka z krewką, żyła z żyłą, siła z siłą".

4. Do grupy czwartej należą zamawiania unicestwiające chorobę na zasadzie analogii lub kontrastu losów choroby i losów postaci fikcyjnej, np. „Róża i Drach szli przez potok. Drach utonął, róża znikła”. W tym typie zamówień, według Obrębskiego, ,choroba i postać fikcyjna są traktowane równorzędnie. Losy ich są uzależnione wyłącznie od ustosunkowania się do nich zamawiacza" ${ }^{\prime 18}$.

5. Inaczej jest $w$ grupie następnej - zamawianiach epicznych (legendowych), gdzie „losy choroby są uzależnione od postaci fikcyjnej, którą jest zazwyczaj postać pochodząca z panteonu chrześcijańskiego. Postać ta unicestwia też często chorobę za pomocą znanych nam już po części zamawiań innych typów"19. Znowu więc napotkał tu autor indeksu trudności klasyfikacyjne: teksty rozbudowane, o strukturze nadrzędno-podrzędnej mogą zawierać w sobie, jak w szkatułce, prostsze typy zamówień. Tak jest w przytoczonym przykładzie: „Szło siedemdziesiąt i dwu zastrzałów. Spotkał się z nimi Pan Bóg. - «Gdzież to idziecie, zastrzały?». - «Idziemy Janowi kości łamać». - «Idźcie na drzewa, na skały i łamcie je, a tego Jana zostawcie w spokoju»".

6. Grupa szósta to zamawiania przesuwające termin choroby do czasu, gdy zajdzie czynność nieprawdopodobna. Ilustruje ją tekst zamówienia przeciw krwotokom: „Na Osijańskiej górze stała studnia kamienna, szła tam dziewczyna kamienna, miała kamienne wiadra, kamienne koromysła, kamienną kosę, cała była kamienna. Gdy ona stamtąd wody przyniesie, wtedy z rodzonego, ochrzczonego sługi Bożego N.N. krew popłynie"20.

7. W grupie siódmej - zamawianiach w formie modlitwy - wydziela Obrębski cztery podgrupy: zamawianie-modlitwę do drzewa, do księżyca, do rzeki i do węża. Jest ona dla niego tak oczywista, że przykładów nie przytacza.

${ }^{17}$ J. Obrębski, Indeks..., s. 7.

${ }^{18}$ Ibidem, s. 8.

${ }^{19}$ Ibidem.

${ }^{20}$ Zamówienia ujęte przez J. Obrębskiego w grupy 4-6 stanowią odpowiedniki jednego ze stałych segmentów kompozycyjnych zamówienia - jego części narracyjnej z prezentacją działań w mitycznym czasie. Cf. S. Niebrzegowska-Bartmińska, op. cit., s. 155-158. 
8. Grupa ósma - zamawiania, w których zawarte jest odliczanie choroby $^{21}$ - również została podzielona na podgrupy, w tym wypadku trzy: zamawiania-odliczania liczbowe (,Był tu żółw, miał 9 żon, z 9 do 8, z 8 do 7 itd. - z 2 do jednej, z jednej nic i sam żebyś znikł”), literowe (,Abrakadabra, Abrakadabr, Abrakadab itd., aż do Ab, A”) i przedmiotowe (,Puchlino, psia krew, tak wielka jak jabłko, z jabłka jak orzech, z orzechu jak bób, z bobu jak groch, z grochu jak mak, z maku jak nic").

9. I wreszcie grupa ostatnia: zamawiania polegające na recytowaniu obcojęzycznych formułek, jak np. „Sator, arepo, tenet, opera, rotas”. Odmianą tego typu zamawiań, polegającą na zastosowaniu do nich zasady odliczania, miałyby być teksty zaliczone do grupy poprzedniej, w których zawarte jest literowe odliczanie choroby.

Oceniając tę pierwszą systematykę zamówień w polskiej literaturze przedmiotu, należy przede wszystkim pamiętać, że nie była ona opracowaniem autonomicznym, opartym na materiale zgromadzonym i zinterpretowanym przez jej autora. Powstała na potrzeby indeksu do cudzej pracy, na marginesie systematyzowania znacznie obszerniejszego materiału z zakresu całej medycyny ludowej. Józef Obrębski nie stawiał sobie ambitniejszego zadania niż tylko sklasyfikowanie zamówień ze ,stanowiska czysto opisowego"; takie ujęcie uważał za wystarczające, by ułatwić czytelnikom książki Biegeleisena korzystanie z zawartego w niej materiału. Musiał natomiast zdawać sobie sprawę - bo sygnalizował to w swoich komentarzach - że występujące w źródłach etnograficznych różnorodne typy zamówień wymagałyby znacznie bardziej przemyślanej, analitycznej systematyki, opartej na spójnym systemie kryteriów. Sam, dzieląc teksty zamówień według motywów, opierał się na kryterium treści; wyodrębniając rozkazy, modlitwy, odliczania, formuły obcojęzyczne i teksty epickie, uwzględniał kryterium formy; wreszcie, wskazując na przypisanie poszczególnych zamówień do odpowiadających im chorób, odwoływał się do kryterium funkcji. W jego rozumieniu była to systematyka ,ze stanowiska czysto opisowego" ${ }^{, 22}$, abstrahująca od pytań genetycznych czy psychologicznych. Tak sproblematyzowaną propozycję można traktować jako poważny zarys obejmującej całość materiału systematyki zamówień.

${ }^{21}$ O odliczaniu malejącym i rosnącym w zamówieniach, równoznacznym z intencjonalnym unicestwieniem choroby. Cf. S. Niebrzegowska-Bartmińska, op. cit., s. 165-166.

${ }^{22}$ J. Obrębski, Indeks..., s. 3. 
W momencie, gdy Józef Obrębski zaproponował swoją systematykę, korpus tekstów zamówień, rozsiany po polskich pracach ludoznawczych z XIX i trzech pierwszych dekad XX wieku był bardzo bogaty (to z niego właśnie obficie korzystał Biegeleisen, który nie prowadził własnych badań terenowych). Przeglądając roczniki „Wisły”, „Zbioru Wiadomości do Antropologii Krajowej", XIX-wieczne tomy Ludu Kolberga i inne edycje materiałów etnograficznych, uświadamiamy sobie, że w owym czasie prawie każdy badacz terenowy, nierzadko na marginesie innych prac, rejestrował teksty zamówień. Czyniono to przede wszystkim w ramach zbierania materiałów z zakresu medycyny ludowej. Większość etnografów notowała jedynie teksty zamówień i w swoich opracowaniach umieszczała je przy opisach sposobów leczenia poszczególnych chorób - zgodnie z przyjętym wzorcem monografii ludowego lecznictwa. Niektórzy badacze (jak np. Michał Federowski, Julian Talko-Hryncewicz czy Franciszek Wereńko) podawali jednak opisy całej praktyki leczniczej towarzyszącej zamówieniu, zdając sobie bez wątpienia sprawę z nierozerwalności aspektu werbalnego, akcjonalnego i przedmiotowego $\mathrm{w}$ akcie zamawiania; $\mathrm{z}$ tego, że jest on magicznym mówieniem-działaniem ${ }^{23}$. Zatrzymywali się też nad postaciami „znachorów”, jak najczęściej nazywano „osoby piastujące godność lekarsko-guślarską" ${ }^{24}$; interesowali się społecznymi aspektami ich umiejętności i wiedzy oraz kontekstem wierzeniowym magicznego leczenia ${ }^{25}$.

23 „Tekst słowny zamówienia jest częścią większej «polimorficznej całości», na którą obok słów składają się też czynności, przedmioty, czas i miejsce, co pozwala traktować zamówienie jako szeroko pojęty tekst kultury i działanie magiczne". S. Niebrzegowska-Bartmińska, op. cit., s. 165-166. Więcej o zamawianiu jako magicznym akcie sprawczym: ibidem, s. 187-194. O magicznym mówieniu-działaniu porównaj szerzej w mojej monografii Klatwa. Rzecz o ludowej magii słowa, Warszawa 2010.

${ }^{24}$ W. Siarkowski, Materiaty do etnografii ludu polskiego z okolic Kielc, cz. 2, ,Zbiór Wiadomości do Antropologii Krajowej” t. 3, 1879, s. 50.

${ }^{25}$ Cf. m.in.: M. Federowski, Lud okolic Żarek, Siewierza i Pilicy. Jego zwyczaje, sposób życia, obrzędy, podania, gusła, zabobony, pieśni, zabawy, przysłowia, zagadki i właściwości mowy, t. II, Warszawa 1889, s. 227-229, 246-248; W. Siarkowski, op. cit., s. 50-51; J. Talko-Hryncewicz, Zarysy lecznictwa ludowego na Rusi Południowej, Kraków 1893, s. 23-26; M. Udziela, Medycyna i przesady lecznicze ludu polskiego. Przyczynek do etnografii polskiej, Warszawa 1891, s. 46-48; F. Wereńko, Przyczynek do lecznictwa ludowego, Kraków 1896, s. 2-11. 
Henryk Biegeleisen i Józef Obrębski, przystępując do badań nad ludowym lecznictwem, mieli do dyspozycji, oprócz wielkiej liczby przyczynków materiałowych z tego zakresu, także kilka poważnych monografii polskiej i wschodniosłowiańskiej ${ }^{26}$ medycyny ludowej, zawierających w sumie kilkaset tekstów zamówień. Wymieńmy najważniejsze. Ksiądz Władysław Siarkowski (Materiały do etnografii ludu polskiego z okolic Kielc, cz. 2, 1879) opublikował pokaźną, zbieraną przez lata pracy terenowej na Kielecczyźnie kolekcję ok. 30 tekstów zamówień (które nazywał „,zażegnywaniami”); nie próbował ich jednak klasyfikować. Julian Talko-Hryncewicz (Zarysy lecznictwa ludowego na Rusi Południowej, 1893) opracował bardzo bogaty materiał ukraiński, pochodzący w większości z Kijowszczyzny (pow. zwinogródzki) i uzupełnił go danymi z innych obszarów wschodniej Słowiańszczyzny. Franciszek Wereńko (Przyczynek do lecznictwa ludowego, Kraków 1896), wzorując się na układzie monografii Talki-Hryncewicza, ogłosił podobne opracowanie materiału zebranego w pow. lepelskim i borysowskim na Białorusi. Także autorzy monografii poszczególnych okolic czy wsi umieszczali w nich rozdziały poświęcone medycynie ludowej. Znaczącą kolekcję zamówień znajdujemy choćby w monografii Michała Federowskiego Lud okolic Żarek, Siewierza i Pilicy (1889), w której uczony ten wśród zamawiań wydziela zażegnywania, określania i modlitwy, a także dokumentuje formuły i praktyki „guseł szkodzących i ochraniających, uroków oraz czarów”27. Nie ulega wątpliwości, że Obrębski, w okresie, kiedy pracował nad indeksem do Biegeleisena, był dobrze obznajomiony $\mathrm{z}$ tym zasobem źródłowym. W recenzji wypowiedział się z aprobatą o książkach Talki-Hryncewicza oraz Udzieli: ,pod względem sposobu podejścia do przedmiotu i metody opracowania pozostaną [one] niedościgłym wzorem dla Biegeleisena"28.

W pierwszym z wymienionych dzieł znajdujemy krótki zarys klasyfikacji tekstów zamówień, oparty na innych założeniach niż późniejsza propozycja Obrębskiego. Julian Talko-Hryncewicz rozpatruje zamówienia

${ }^{26} \mathrm{Na}$ temat silnych związków XIX-wiecznej etnologii polskiej ze wschodnimi obszarami I Rzeczypospolitej, zamieszkałymi przez ludność ukraińską, białoruską i litewską, cf. m.in. Z. Jasiewicz, Poczq̨tki polskiej etnologii i antropologii kulturowej (od końca XVIII wieku do roku 1918), Poznań 2011, s. 45-46.

${ }^{27}$ M. Federowski, op. cit., s. 227-264.

${ }^{28}$ J. Obrębski, [recenzja], s. B255. 
przede wszystkim z punktu widzenia ich genezy; obok kryterium genetycznego uwzględnia też funkcjonalne i formalne:

W samym charakterze zamawiań wyróżniamy dwa rodzaje. Jeden z nich przypomina wierzenia wschodnio-indyjskie ${ }^{29}$ i bywa w pewnych chorobach używanym, jak np. na różę, na płaksy u dzieci, na uroki itd., w których to zamawianiach chorobę zapędzają, skąd przyszła: na wiatry, pola, lasy, góry, doliny, wody i błota i na ludzi, którzy ją nasłali. Inne zamawiania noszą znowu w sobie piętno kościelnej cywilizacji wschodnio-bizantyjskiej i te więcej są używane w chorobach macicznych, otrzęsieniach się itd. Niektóre z nich noszą charakter modlitw pomieszanych z przesądnymi wierzeniami, w których znachor prosi Boga, Najświętszą Pannę lub świętych pańskich, aby raczyli uwolnić od choroby sługę swego (,raba swojeho"), inne znowu są legendami religijnymi, znacznie w ustach ludu zmienionymi ${ }^{30}$.

W tym komentarzu lekarza i antropologa ze Zwinogródki i w systematyce Obrębskiego można wskazać momenty wspólne: motyw zapędzania/wypędzania choroby, uwalniania od niej przez postacie nadprzyrodzone/fikcyjne, zamawiania w postaci legend religijnych/zamawiania epiczne (legendowe). Obrębski, opracowując swoją systematykę, mógł sięgać do tego passusu z monografii Talki-Hryncewicza - fragmentu, który nie jest pełną klasyfikacją tekstów zamówień, zawiera jednak idące $\mathrm{w}$ tę stronę wartościowe intuicje.

\section{3}

By dopełnić ten przyczynek do dziejów polskich badań nad zamówieniem, zapytajmy jeszcze o ewentualne nawiązania do systematyki Obrębskiego w pracach opublikowanych niedługo po jego Indeksie.

W roku 1933, w Krakowie, ukazała się drukiem monografia Obrzęd kolędowania u Stowian i Rumunów autorstwa Piotra Caramana, rumuńskiego etnografa i folklorysty, ucznia Jana Stanisława Bystronia. Swoją analizę kolęd życzeniowych z badanego kręgu kulturowego - ich struktury, genezy i funkcji - autor umieścił na szerszym tle magicznych praktyk

${ }^{29} \mathrm{Na}$ temat koncepcji indyjskiego pochodzenia Słowian i indyjskiej genezy słowiańskich treści kultury w XIX-wiecznej etnologii polskiej, cf. Z. Jasiewicz, op. cit., s. 79, 95,120 .

${ }^{30}$ J. Talko-Hryncewicz, op. cit., s. 31. 
słownych, wśród których uwzględnił także zamówienia (nazywane zaklinaniami). W jego ujęciu zamówienia chorób to zaklinania typu negatywnego (egzorcyzacje). Pisał:

Zaklinania-formuły magiczne, którym towarzyszą odpowiednie zabiegi, są właśnie środkami, za pomocą których człowiek może usunąć od siebie lub od kogoś innego zło: chorobę lub jaką́s ułomność, może też zesłać ją na kogoś. W innych wypadkach może ściągnąć na siebie lub kogoś innego jakieś dobro czy zaletę: zdrowie, urodę itd. W pierwszym wypadku, gdy zaklinanie ma na celu wypędzenie lub zniszczenie zła, mamy do czynienia z egzorcyzacją, tj. w ogólniejszym znaczeniu tego słowa z typem negatywnym. W przypadkach zaś ściagania zła lub dobra na kogoś mamy typ pozytywny. Bez względu na cel, jaki mają zaklinania, przedstawiają one dwie wyraźne formy:

1. Bezpośrednią, tj. taką, która odwołuje się bezpośrednio do duchów, sprowadzających zło, lub co rzadsze, dobro, a niekiedy do samego zła lub dobra upostaciowanego, aby je wypędzić lub ściagnąć na kogoś. To odwoływanie wykonuje zaklinacz czasem w tonie proszącym, za pomocą pochlebstwa czy obietnicy, a w innych wypadkach w tonie władczym za pomocą pogróżek i przekleństw.

2. Pośrednią. Zaklinacz nie występuje wcale w formule, pierwiastek subiektywno-liryczny znika zupełnie, a na jego miejsce pojawia się pierwiastek obiektywny, epiczno-dramatyczny. Zaklinanie w pierwszej części opowiada (bez udziału zaklinacza) zdarzenie, dzięki któremu wedle wierzeń ludowych bohater zaklinania zachorował lub utracił jakąś zaletę, np. urodę. W większości wypadków złe duchy spotykały go i przyprawiały o chorobę, albo odbierały mu piękność. W drugiej części zaklinania mamy do czynienia z interwencją potęgi nadprzyrodzonej (...). Siły te walczą ze złem i zwyciężają, unicestwiając je lub wypędzając, przez co poszkodowany odzyskuje zdrowie, piękność itd. Niekiedy forma ta jest jeszcze prostsza: bez pomocy jakiejkolwiek interwencji wypowiada się pragnienie zaklinającego, i tak chory już odzyskał zdrowie, brzydki stał się pięknym itd. ${ }^{31}$

W tej próbie analitycznego spojrzenia na typy zaklinań można dostrzec niewatpliwe pokrewieństwa $\mathrm{z}$ systematyką zaproponowaną przez Obrębskiego. Caramanowskie zaklinania bezpośrednie odpowiadają wyróżnionym w niej zamówieniom opartym na motywie wypędzania choroby. Obaj badacze mają też świadomość, że formuły te mogą być różnymi aktami mowy: rozkazem, pogróżka, prośbą, modlitwą. Zaklinania pośred-

${ }^{31}$ P. Caraman, Obrzęd kolędowania u Stowian i Rumunów. Studium porównawcze, Kraków 1933, s. 428-429. 
nie, zawierające ,pierwiastek epiczno-dramatyczny”, to z kolei nic innego niż piąta grupa tekstów w systematyce Obrębskiego - zamawiania epiczne (legendowe).

Caraman i Obrębski znali się osobiście, obaj studiowali i pracowali naukowo w Studium Słowiańskim Uniwersytetu Jagiellońskiego. Na to, że obaj poświęcili uwagę tekstom zamówień (trudno sobie wyobrazić, by nie rozmawiali ze sobą na ten temat), musiały mieć wpływ także zainteresowania ich nauczycieli problematyką magii słowa ${ }^{32}$. W interesującym nas okresie (w 1927 roku) spod pióra Jana Stanisława Bystronia wyszedł szkic Przeżytki wiary w magicznq moc stowa ${ }^{33}$. Kazimierz Moszyński z kolei był nie tylko autorem rozbudowanej klasyfikacji praktyk submagicznych i magicznych (wśród których wydzielił praktyki translacyjne, transmisyjne, sympatetyczne, kreacyjne i incepcyjne $)^{34}$; w kontekście systematyki magii poświęcił także dużo uwagi m.in. zamówieniom. Konstatował: „Bardzo zwartą i charakterystyczną grupę magicznych praktyk w szerszym znaczeniu ostatniego słowa stanowią zaklinania i zamawiania, wyodrębniające się ostro spośród wszelkiej pozostałej magii, ale za to mieszające się po części z modlitwami i bezpośrednimi nakazami” ${ }^{35}$. Choć wszystko, co Moszyński w Kulturze ludowej Stowian napisał o zamówieniach ${ }^{36}$, nosi charakter rozproszonej po wielu miejscach tego monumentalnego dzieła monografii zagadnienia i choć jest pierwszym w polskiej literaturze przedmiotu tak spójnym myślowo i krytycznym jego ujęciem, to - co ciekawe nauczyciel Obrębskiego nie próbował systematyzować zamówień. Pytanie, z jakich powodów nie wykorzystał i nie dopracował propozycji swojego ucznia, musi chyba pozostać bez odpowiedzi.

\footnotetext{
${ }^{32}$ Warto wspomnieć, że we wstępie do swojej monografii P. Caraman dziękuje m.in. profesorowi Moszyńskiemu, „który okazał żywe zainteresowanie dla mojej pracy, udzielając mi nieraz bardzo trafnych uwag lub polecając mi różnych dobrych autorów z tego zakresu". Ibidem, s. III.

${ }^{33}$ Kolejne wydanie szkicu: J.S. Bystroń, Przeżytki wiary w magicznq moc słowa, w: idem, Tematy, które mi odradzano. Pisma etnograficzne rozproszone, oprac. L. Stomma, Warszawa 1980, s. 204-218.

${ }^{34}$ Cf. K. Moszyński, Kultura ludowa Stowian, cz. II: Kultura duchowa, z. 1, s. 267269.

${ }^{35}$ Ibidem, s. 300.

${ }^{36}$ Cf. ibidem, s. 229-239, 300-302; K. Moszyński, Kultura ludowa Stowian, cz. II: Kultura duchowa, z. 2, s. 1507-1511.
} 


\section{4}

Lecznictwo ludu polskiego Henryka Biegeleisena zostało po raz drugi opublikowane pod koniec lat osiemdziesiątych XX wieku w formie reprintu (1986). Wielka szkoda, że nie wykorzystano tej okazji do korekty licznych błędów autorskich i drukarskich w książce oraz do uzupełnienia jej o opracowany przez Obrębskiego Indeks. Pozostaje on, niezależnie od swojej funkcji służebnej wobec pracy Biegeleisena, istotnym przyczynkiem do dziejów polskich badań nad zamówieniami. Przyczynkiem bardzo niesłusznie zapomnianym. 